\title{
Threat of unemployment and cardiovascular risk factors: longitudinal study of quality of sleep and serum cholesterol concentrations in men threatened with redundancy
}

\author{
Ingrid Mattiasson, Folke Lindgärde, Jan Åke Nilsson, Töres Theorell
}

Department of Medicine, University of Lund, Section for Preventive Medicine, Malmö Genera Hospital, S-214 01 Malmö, Sweden

Ingrid Mattiasson, PHD, registrar

Folke Lindgärde, PHD, senior registrar

Department of Statistics and Data Processing,

Malmö General Hospital, S-214 01 Malmö, Sweden Jan Åke Nilsson, BA, statistician

National Institute for Psychosocial Factors and Health, Karolinska Institute, S-104 01

Stockholm, Sweden

Töres Theorell, PHD, professor

Correspondence to: Dr Ingrid Mattiasson, Department of Medicine, Malmö General Hospital, S-214 01 Malmö, Sweden.

\section{Abstract}

Objective-To assess whether the threat of unemployment affects risk factors for cardiovascular disease.

Design-Longitudinal study of a cohort of middle aged shipyard workers followed up for a mean of $6 \cdot 2$ (SD 1.9) years and a group of controls observed for the same period. The first investigation took place during a period of relative economic stability for the shipyard and the second during the phase of its closure.

Setting-An age cohort health screening programme in Malmö, Sweden.

Participants -715 Male shipyard workers and 261 age matched male controls.

Main outcome measures-Changes in 19 variables related to the risk of cardiovascular disease, and psychological variables, alcohol consumption, smoking, and dietary habits as assessed by questionnaire.

Results-Serum cholesterol concentrations increased more (mean 0.25 (SD 0.68 ) $\mathrm{mmol} / \mathrm{l} v 0.08$ $(0.66) \mathrm{mmol} / \mathrm{l})$ and serum calcium concentrations decreased less $(-0.06(0.10) \mathrm{mmol} / \mathrm{l} v-0.08(0.09)$ $\mathrm{mmol} / \mathrm{l})$ in the shipyard workers than in the controls. A correlation was found between scores for sleep disturbance and changes in serum cholesterol concentration. In the whole series there was a greater increase in serum cholesterol concentrations among men threatened with unemployment (437/976; $\mathbf{4 4 . 8 \% )}$ than among those who were not. In stepwise regression analysis the change in serum cholesterol concentration was correlated with changes in haemoglobin concentration, body weight, and serum triglyceride and calcium concentrations. A positive correlation was found between change in cholesterol concentration and change in blood pressure, indicating that the overall risk profile had worsened among men with increased serum cholesterol concentrations.

Conclusions-Risk of unemployment increases the serum cholesterol concentration in middle aged men, the increase being more pronounced in those with sleep disturbance. The increase in serum cholesterol is related to changes in other established risk factors for cardiovascular disease. These findings might partly explain the excessive mortality due to cardiovascular disease recorded among the unemployed and people with sleep disturbance.

\section{Introduction}

Changes in the unemployment rate and business failure rate in nine countries have been positively correlated with changes in heart disease mortality two to five years later. The correlations persisted even when adjustment was made for consumption of alcohol, cigarettes, and animal fats and other factors. ${ }^{1}$ In a corresponding Swedish study a tendency was found for unemployment to be higher in areas with above average male mortality from ischaemic heart disease, ${ }^{2}$ and in a British study mortality due to heart disease was higher among unemployed men. ${ }^{3}$ A significant increase in morbidity was recorded in a group of factory workers when they were threatened with redundancy and subsequently laid off. ${ }^{4}$ The relation between unemployment and physical and mental health has been reviewed. ${ }^{56}$

A questionnaire survey during a two year observation period when Denmark's largest shipyard was closed found a relation between the threat of job loss and the presence of anxiety and depression. ${ }^{7}$ A possible consequence of psychosocial stress is sleep disturbance, and a six year follow up study of adults showed mortality to be high among men with sleep disturbance. ${ }^{8}$ Epidemiological studies in Alameda County, United States, over nine years also showed mortality to be increased among adults sleeping less than seven hours and more than nine hours even when a large number of confounding variables were taken into consideration. ' Hence there is a need for further studies on the effects of unemployment or the threat of unemployment on sleep, psychological variables, and established risk factors for cardiovascular disease.

The aims of this study were twofold. Firstly, we wished to ascertain whether relations existed between the threat of job loss or future unemployment and changes in risk factors for cardiovascular disease (namely, in respect of blood pressure, treatment for blood pressure, blood lipid concentrations, body weight, haemoglobin concentration, and glucose tolerance as well as such lifestyle factors as smoking, alcohol intake, and dietary habits). Secondly, we wished to see whether mental stress and sleep disturbance were related to and might explain possible changes in risk factors for coronary heart disease. The study group consisted of 715 male workers at a shipyard in Malmö in southern Sweden who had been followed up for six years. The first examinations took place during a period of relative economic stability for the company and the second during its closure phase.

\section{Subjects and methods}

EMPLOYMENT SETTING

Kockums AB, Malmö, is a shipbuilding yard, which until June 1988 consisted of a mercantile side and a naval side (Kockums Marine, producing submarines). Only day shifts were worked at the yard. The decline of the Swedish shipbuilding industry began at the end of the 1970s, and Kockums was the last existing yard producing new vessels. In February 1986 the govern- 
ment decided that the mercantile side of Kockums should be closed, employees being given advance notice in March. Final notice was given in January 1987, different durations of severance leave being granted (fig 1). Owing to experience from the closure of other shipyards government support for the creation of new jobs was substantial. People who could be reemployed in Kockums Marine and those who would be offered early retirement were informed. Personnel aged 58.3 years or more were offered early retirement on full pay for the first 21 months and $95 \%$ of their wages for the remaining time until they reached the normal retirement age of 65 ; all employees in this age group accepted, mainly because of the difficulty for older people in finding new jobs. The remaining personnel faced an uncertain future for varying periods during 1987; in the event most obtained new jobs within a year and before their employment at Kockums had ended.

\section{STUDY GROUP}

Of the 2588 employees in October 1986, 1384 men had been born between 1926 and 1949 and lived in the city of Malmö. All were invited to participate in a health screening programme at the department of medicine, section for preventive medicine, Malmö General Hospital. Of these 1384 men, 1181 belonged to age cohorts that had already been screened. The invitation was in the usual standardised form used for the screening programme, and no indication was given that uncertainty about employment was the real reason for the investigation. The examinations started in March 1987 and ended in January 1988. Of the $1016(73.4 \%)$ men who accepted the invitation, 854 belonged to age cohorts that had been investigated previously, and for $715(83.7 \%)$ of these men data from at least one earlier health screening since 1976 were available.

\section{CONTROLS}

Controls were obtained from the screening programme database by random selection of 332 previously screened men matched for age with the 1181 shipyard workers who had previously been screened. To minimise any effect of seasonal variation in serum cholesterol concentration roughly every fifth person tested in a given age cohort was selected as a control. These 332 men were then extended the same screening invitation, $261(78.6 \%)$ accepting. There were no exclusions, employment at the shipyard being the sole exclusion criterion. Thus the 261 controls were a random subsample of male Malmö residents, comparable with the study population with regard to age, screening history, and (as age cohort screening takes only a few months) duration of follow up.

\section{HEALTH EXAMINATIONS}

Age cohort health screening has been performed at the preventive medicine section of the department of medicine at Malmö General Hospital since 1974. Consecutive, mainly middle aged subjects born during 1921 to 1949 (age at screening 29 to 61) have been invited to participate. In all, over 40000 health examinations have been carried out. Six age cohorts have been investigated twice. The average participation rate is $75 \%$. The screening procedure has been described. ${ }^{10} \mathrm{~A}$ relative weight index (actual/ideal weight) is calculated according to standardised weight tables. " Blood pressure is measured with the patient supine after 10 minutes' rest. In some age cohorts an oral glucose tolerance test $\left(30 \mathrm{~g}\right.$ glucose $/ \mathrm{m}^{2}$ body surface area) is performed, blood glucose being measured fasting and at 120 minutes.

This investigation was performed in the same way as an ordinary screening except that, in addition, partici-

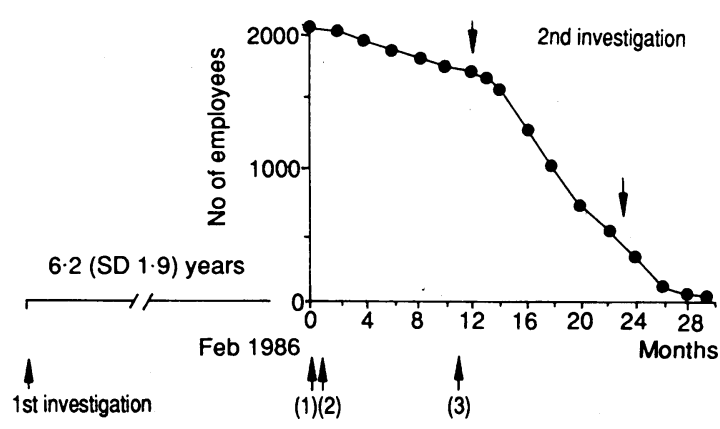

FIG 1-Numbers of employees in mercantile side of shipyard from February 1986, when decision to close was made, until definite closure in summer 1988. Arrows above plot indicate start and finish of follow up examinations. Arrows below graph denote (1) government decision to close mercantile yard, (2) advance notice to employees, (3) final notice of impending lay offs

pants answered a questionnaire designed to evaluate muscle tension, sleep disturbance, anxiety, and depression. The indices for depression and anxiety were translated and adapted to Swedish conditions from a short form based on factor analysis of the general health questionnaire. ${ }^{12}$ The sleep disturbance index has been used in several studies. ${ }^{1314}$ The muscle tension index has been used and its psychometric properties analysed in two recent studies, in which muscle tension was shown to be related both to work environmental factors and to such physiological variables as plasma testosterone concentration. ${ }^{1516}$ The appendix gives details of the questionnaire. All answers were scored "yes" $=1$, "no" $=0$. As scores were calculated only for those who answered all of a given group of questions the exclusion rate was $11 \%$ for muscle tension and below $10 \%$ for the remaining psychological variables. The mean overall exclusion rate was $4 \cdot 9 \%$.

\section{STATISTICAL METHODS}

All statistical analyses were performed with the statistical analysis system MICROVAX II. The following statistical tests were used: Student's $t$ test; $F$ statistic to test the assumption that the variances were equal; multiple linear regression; stepwise multiple linear regression; analyses of covariance; $\chi^{2}$ test; Pearson's product moment correlation; Spearman's rank correlation. Values are given as means and one standard deviation (SD).

\section{Results}

Mean age at the second examination was $51 \cdot 6(6 \cdot 0)$ years (range $37 \cdot 9-61 \cdot 6$ ) in the study group and $51 \cdot 2$ $(6 \cdot 3)$ years (range $37 \cdot 6-61 \cdot 0$ ) in the controls. The mean intervals between the first and second screenings in the two groups were $6.2(1.9)$ and $6.4(1.9)$ years respectively. A total of $290(40.6 \%)$ men in the study group had come to Sweden as adult immigrants as compared with only $21(8 \cdot 0 \%)$ of the controls. As this discrepancy might have affected the results we also analysed values in native Swedes and immigrants in the study group separately. In response to the question "Have you been threatened with job loss?" 428 (59.9\%) men in the study group and nine (3.4\%) controls answered "yes."

Table I shows some of the baseline values recorded at the first screening in the study and control groups. There were no appreciable differences between the groups in any variable with the exception of a significantly higher forced vital capacity among the controls. Analysis of changes in values at the second investigation, however, showed significant differences between the groups in two variables. Serum cholesterol concentrations had increased more in the study group, and serum calcium concentrations had decreased in both 
groups but to a lesser extent in the study group (table I). The two groups were comparable with regard to changes in triceps skinfold thickness, erythrocyte sedimentation rate, white cell count, urate and creatinine concentrations, aspartate and alanine aminotransferase activities, and pulse rate.

Changes between the two investigations in scores for antihypertensive treatment, alcohol intake, and smoking analysed by $\chi^{2}$ test showed no significant differences between the groups (data not shown). Nutrition scores at the second investigation suggested that the controls had somewhat better dietary habits than the study group $(4 \cdot 7(1 \cdot 8) v 4 \cdot 4(1 \cdot 7) ; \mathrm{p}=0.04$.

\section{PSYCHOLOGICAL VARIABLES}

Table II gives the mean values for some relevant psychological variables obtained at the second health screening. The only significant difference between the study group and the controls was a higher mean value for sleep disturbance in the study group $(p=0.04)$. There was a remarkable difference in values for psychological variables between immigrants and native Swedes in the study group $(p<0.0001$ for all four variables). Native Swedes in the control group had slightly higher mean values for these variables than had native Swedes in the study group.

All men in the study group aged 58.3 years or more $(n=106 ; 14 \cdot 8 \%)$ accepted early retirement on full pay. Scores for muscle tension, sleeping problems, anxiety, and depression were all significantly lower in this subgroup than in the younger men. No such age related differences were found among the controls. In general the older controls had higher mean values for all psychological variables, the score for sleep disturbance being significantly higher in these men (table II).

Men in the study and control groups reporting threatened job loss had significantly higher scores for sleep disturbance, depression, and anxiety than other men (data not shown).

CHANGES IN SERUM CHOLESTEROL CONCENTRATIONS IN RELATION TO LIFESTYLE AND SOCIOECONOMIC FACTORS

Change in the serum cholesterol concentration was correlated with age in all subjects $\left(r_{s}=-0 \cdot 167\right.$;

TABLE I-Changes in clinical and laboratory values in study group and controls compared with baseline values recorded at first screening $6 \cdot 2(S D 1 \cdot 9)$ years previously. All values are means $(S D)$

\begin{tabular}{|c|c|c|c|c|}
\hline & \multicolumn{2}{|c|}{ Study group ( $n=715$ ) } & \multicolumn{2}{|c|}{ Controls $(n=261)$} \\
\hline & Baseline value & Change & Baseline value & Change \\
\hline Weight $(\mathbf{k g})$ & $76 \cdot 3(10 \cdot 3)$ & $1 \cdot 8(3.9)$ & $77 \cdot 4(11 \cdot 6)$ & $1 \cdot 7(4.5)$ \\
\hline Actual/ideal weight & $1.09(0 \cdot 13)$ & $0.03(0.06)$ & $1 \cdot 07(0 \cdot 15)$ & $0.03(0.06)$ \\
\hline Systolic blood pressure $(\mathrm{mm} \mathrm{Hg})$ & $124 \cdot 4(12 \cdot 8)$ & $-2 \cdot 0(13 \cdot 1)$ & $124 \cdot 7(12 \cdot 8)$ & $-2 \cdot 2(14 \cdot 1)$ \\
\hline Diastolic blood pressure (mm Hg) & $84 \cdot 6(8 \cdot 3)$ & $-0 \cdot 1(8 \cdot 0)$ & $83 \cdot 7(8 \cdot 6)$ & $0.6(8 \cdot 0)$ \\
\hline Haemoglobin $(g / 1)$ & $147 \cdot 4(9 \cdot 0)$ & $1 \cdot 7(7 \cdot 7)$ & $147 \cdot 8(9 \cdot 3)$ & $1 \cdot 0(7 \cdot 1)$ \\
\hline Calcium $(\mathrm{mmol} / \mathrm{l})$ & $2 \cdot 39(0 \cdot 09)$ & $-0.06(0 \cdot 10)$ & $2.39(0.08)$ & $-0.08(0.09)^{\star \star}$ \\
\hline Cholesterol $(\mathrm{mmol} / \mathrm{l})$ & $5.54(1.00)$ & $0.25(0.68)$ & $5.67(1.03)$ & $0.08(0.66)^{\star \star \star}$ \\
\hline Triglycerides $(\mathrm{mmol} / \mathrm{l})$ & $1.38(0.81)$ & $-0.01(0.83)$ & $1.45(0.86)$ & $-0 \cdot 10(0 \cdot 73)$ \\
\hline$\gamma$-Glutamyl transferase $(\mu \mathrm{kat} / \mathrm{l})$ & $0.54(0.51)$ & $-0.01(0.48)$ & $0.54(0.42)$ & $-0.002(0.46)$ \\
\hline Fasting glucose $(\mathrm{mmol} / \mathrm{l})$ & $4.98(0 \cdot 71)$ & $0.08(0.77)$ & $4.94(0.74)$ & $0.05(1.17)$ \\
\hline Glucose $120 \mathrm{~min}$ after loading ( & $5 \cdot 06(1 \cdot 70)$ & $0.32(1.61)$ & $5 \cdot 17(1 \cdot 24)$ & $0 \cdot 27(2 \cdot 20)$ \\
\hline Forced vital capacity (1) & $4.46(0.87)$ & $-0.24(0.73)$ & $4.74(0.92)^{\star \star \star \star}$ & $-0.22(0.77)$ \\
\hline
\end{tabular}

$\star \star \mathrm{p}<0 \cdot 01,{ }^{\star \star \star} \mathrm{p}<0.001$ Compared with study group.

fGlucose loading test' given to 490 men in study group and 170 controls.
TABLE III-Changes in serum cholesterol concentrations compared with baseline values recorded at first screening in study group and controls subdivided by age and (study group only) native origin. Values are means $(S D)$

\begin{tabular}{|c|c|c|c|c|c|}
\hline & \multirow{2}{*}{$\begin{array}{c}\text { Age } \\
\text { (years) }\end{array}$} & \multirow[b]{2}{*}{ No } & \multicolumn{2}{|c|}{$\begin{array}{l}\text { Serum cholesterol } \\
(\mathrm{mmol} / \mathrm{l})\end{array}$} & \multirow[b]{2}{*}{ p Value } \\
\hline & & & Baseline & Change & \\
\hline \multicolumn{6}{|l|}{ Study group: } \\
\hline Native Swedes & $\left\{\begin{array}{l}<58 \cdot 3 \\
\geqslant 58 \cdot 3\end{array}\right.$ & $\begin{array}{r}346 \\
79\end{array}$ & $\begin{array}{l}5.57(1.05) \\
5.78(1.0)\end{array}$ & $\begin{array}{l}0.25(0.70) \\
0.10(0.68)\end{array}$ & 0.094 \\
\hline Immigrants & $\left\{\begin{array}{l}<58 \cdot 3 \\
\geqslant 58 \cdot 3\end{array}\right.$ & $\begin{array}{r}263 \\
27\end{array}$ & $\begin{array}{l}5.44(0.95) \\
5.49(0.88)\end{array}$ & $\begin{array}{l}0.32(0.67) \\
0.04(0.50)\end{array}$ & 0.035 \\
\hline Controls & $\left\{\begin{array}{l}<58 \cdot 3 \\
\geqslant 58 \cdot 3\end{array}\right.$ & $\begin{array}{r}221 \\
40\end{array}$ & $\begin{array}{l}5.61(1.05) \\
6.00(0.94)\end{array}$ & $\begin{array}{l}0.06(0.69) \\
0.15(0.49)\end{array}$ & 0.34 \\
\hline
\end{tabular}

^For differences in change between age groups (analysis of variance).

$\mathrm{p}<0.0001$ ). All men in the study group aged 58.3 years or more knew at the time of screening that they would be given early retirement on full pay instead of new work. The mean changes in the serum cholesterol concentration in these men was $0.09 \mathrm{mmol} / \mathrm{l}$. By contrast, younger men in the study group had a mean change of $0.28 \mathrm{mmol} / \mathrm{l}$ in their serum cholesterol concentrations $(p=0.007)$. Among the controls there was no significant difference between the age groups.

Of all 976 men in the study and control groups, 437 $(44 \cdot 8 \%)$ reported being threatened with unemployment. The serum cholesterol concentration rose by $0.28 \mathrm{mmol} / \mathrm{l}$ in these men as compared with $0.15 \mathrm{mmol} / \mathrm{l}$ in the remainder $(\mathrm{p}=0.004)$.

Table III shows the changes in serum cholesterol concentrations in native Swedes and immigrants in the study group and in the controls subdivided by age. In the total group the mean change in serum cholesterol concentrations was $0.16(0.69) \mathrm{mmol} / \mathrm{l}$ in native Swedes and $0.29(0.65) \mathrm{mmol} / \mathrm{l}$ in immigrants $(p=0.005)$. In an analysis of covariance including study group $v$ controls as well as native Swedes $v$ immigrants the difference in serum cholesterol concentrations was significant only between the study group and the controls $(p=0.005)$. In neither the study group nor the controls was the change in serum cholesterol concentration significantly correlated with nutrition or alcohol intake score or change in alcohol intake score between the two investigations. Change in nutrition score could not be computed as some questions were not included in the questionnaire at the first screening for the whole group.

The 153 members of the study group who answered "yes" to the question "Have you ever received dietary advice?" had a significantly smaller increase in serum cholesterol concentrations $(0.04 \mathrm{mmol} / \mathrm{l})$ than those who answered "no" $(0.24 \mathrm{mmol} / \mathrm{l})(\mathrm{p}=0.001)$. In multiple linear regression analysis with change in serum cholesterol concentration as the dependent variable and including age, group, native origin, dietary advice, nutrition score, threat of unemployment, and scores for alcohol intake and smoking the variables age, group (shipyard workers $v$ controls), and dietary advice were found to be significantly correlated with change in serum cholesterol value.

TABLE II - Scores for psychological variables and alcohol consumption recorded at second screening in study group and controls subdivided by age and (study group only) native origin. Scores expressed as means $(S D)$

\begin{tabular}{|c|c|c|c|c|c|c|c|c|c|c|c|c|}
\hline & \multirow[b]{2}{*}{$\begin{array}{l}\text { Controls } \\
(\mathrm{n}=261)\end{array}$} & \multirow[b]{2}{*}{$\begin{array}{c}\text { Study group } \\
(\mathbf{n}=715)\end{array}$} & \multirow[b]{2}{*}{$\mathrm{p}$ Value } & \multicolumn{6}{|c|}{ Study group } & \multicolumn{3}{|c|}{ Controls } \\
\hline & & & & $\begin{array}{c}\text { Native } \\
\text { Swedes } \\
(n=425)\end{array}$ & $\underset{(\mathbf{n}=290)}{\operatorname{Immigrants}}$ & $\mathrm{p}$ Value & $\begin{array}{c}\text { Age }<58 \cdot 3 \\
\text { years } \\
(\mathbf{n}=609)\end{array}$ & $\begin{array}{c}\text { Age } \geqslant 58 \cdot 3 \\
\text { years } \\
(n=106)\end{array}$ & $\mathrm{p}$ Value & $\begin{array}{c}\text { Age }<58 \cdot 3 \\
\text { years } \\
(\mathrm{n}=221)\end{array}$ & $\begin{array}{c}\text { Age } \geqslant 58 \cdot 3 \\
\text { years } \\
(\mathbf{n}=40)\end{array}$ & $\mathrm{p}$ Value \\
\hline \multicolumn{13}{|l|}{ Psychological variables: } \\
\hline Muscle tension & $1 \cdot 7(2 \cdot 1)$ & $1 \cdot 8(2 \cdot 2)$ & $0 \cdot 38$ & $1 \cdot 5(1 \cdot 8)$ & $2 \cdot 4(2 \cdot 5)$ & 0.0001 & $1.9(2 \cdot 2)$ & $1 \cdot 4(1 \cdot 7)$ & $0 \cdot 02$ & $1 \cdot 6(2 \cdot 0)$ & $2 \cdot 0(2 \cdot 2)$ & $0 \cdot 36$ \\
\hline Sleep disturbance & $0.6(0.9)$ & $0.8(1.0)$ & 0.04 & $0.6(0.9)$ & $1 \cdot 1(1 \cdot 1)$ & 0.0001 & $0.8(1.0)$ & $0.5(0 \cdot 7)$ & 0.0001 & $0.6(0.9)$ & $0.9(1.0)$ & 0.04 \\
\hline Depression & $0 \cdot 6(1 \cdot 1)$ & $0.6(1.0)$ & 0.43 & $0.4(0.9)$ & $0.8(1 \cdot 1)$ & 0.0001 & $0.6(1 \cdot 1)$ & $0.3(0.3)$ & 0.0001 & $0.6(1 \cdot 1)$ & $0.6(0.6)$ & $0 \cdot 85$ \\
\hline Anxiety & $0.8(1.2)$ & $0.8(1.4)$ & $0 \cdot 38$ & $0 \cdot 6(1 \cdot 1)$ & $1 \cdot 3(1 \cdot 7)$ & 0.0001 & $0.9(1.5)$ & $0.5(0.9)$ & 0.0001 & $0.7(1 \cdot 2)$ & $1.0(0.9)$ & $0 \cdot 31$ \\
\hline Alcohol consumption & $1 \cdot 2(1 \cdot 4)$ & $1 \cdot 1(1 \cdot 4)$ & 0.39 & $1 \cdot 1(1.5)$ & $1.0(1 \cdot 2)$ & 0.09 & $1 \cdot 1(1 \cdot 4)$ & $0 \cdot 7(1 \cdot 1)$ & 0.0007 & $1 \cdot 2(1.4)$ & $1 \cdot 1(1 \cdot 4)$ & 0.72 \\
\hline
\end{tabular}




\begin{tabular}{|c|c|c|c|c|c|c|c|c|c|c|c|c|c|}
\hline \multirow{3}{*}{$\begin{array}{l}\text { Change in } \\
\text { cholesterol } \\
(\mathrm{mmol} / \mathrm{l})\end{array}$} & \multirow[b]{3}{*}{ No of subjects } & \multirow{3}{*}{$\begin{array}{c}\text { Change in } \\
\text { weight } \\
(\mathrm{kg})\end{array}$} & \multirow{3}{*}{$\begin{array}{l}\text { Change in } \\
\text { haemoglobin } \\
(\mathrm{g} / \mathrm{l})\end{array}$} & \multirow{3}{*}{$\begin{array}{l}\text { Change in } \\
\text { triglycerides } \\
(\mathrm{mmol} / \mathrm{l})\end{array}$} & \multirow{3}{*}{$\begin{array}{l}\text { Change in } \\
\text { pulse rate } \\
\text { (beats/min) }\end{array}$} & \multirow{2}{*}{\multicolumn{2}{|c|}{$\begin{array}{l}\text { Change in blood } \\
\text { pressure }(\mathrm{mm} \mathrm{Hg})\end{array}$}} & \multirow{3}{*}{$\begin{array}{l}\text { Change in } \\
\text { forced vital } \\
\text { capacity (1) }\end{array}$} & \multirow{3}{*}{$\begin{array}{c}\text { Change in } \\
\text { calcium } \\
(\mathrm{mmol} / \mathrm{l})\end{array}$} & \multicolumn{2}{|c|}{$\begin{array}{l}\text { Change in } \\
\text { glucose }(\mathrm{mmol} / \mathrm{l})\end{array}$} & \multirow[b]{3}{*}{ Muscle tension } & \multirow{3}{*}{$\begin{array}{c}\text { Sleep } \\
\text { disturbance }\end{array}$} \\
\hline & & & & & & & & & & \multirow{2}{*}{$\begin{array}{c}120 \mathrm{Min} \\
\text { after } \\
\text { loading }\end{array}$} & \multirow[b]{2}{*}{ Fasting } & & \\
\hline & & & & & & Diastolic & Systolic & & & & & & \\
\hline$>-0.5$ & 127 & 0.37 & -2.54 & -0.25 & $-2 \cdot 2$ & -2.52 & -0.66 & $-0 \cdot 19$ & $-0 \cdot 10$ & 0.36 & 0.03 & $1 \cdot 30$ & 0.57 \\
\hline$-0 \cdot 5-0$ & 225 & 1.03 & 0.51 & $-0 \cdot 19$ & $-2 \cdot 4$ & -0.22 & 1.94 & $-0 \cdot 17$ & -0.08 & $0 \cdot 19$ & 0.04 & 1.54 & 0.64 \\
\hline $0-0 \cdot 5$ & 304 & 1.83 & 1.77 & -0.02 & 0.25 & 0.64 & $2 \cdot 86$ & -0.33 & -0.07 & 0.26 & 0.12 & 2.05 & 0.85 \\
\hline $0.5-1 \cdot 0$ & 216 & $2 \cdot 46$ & $3 \cdot 17$ & 0.03 & $-1 \cdot 37$ & 0.31 & 1.54 & -0.21 & -0.05 & 0.52 & 0.09 & 1.72 & 0.76 \\
\hline$>1.0$ & 91 & 4.00 & $4 \cdot 75$ & 0.44 & -0.67 & 1.98 & $4 \cdot 29$ & $-0 \cdot 19$ & -0.05 & $0 \cdot 30$ & 0.02 & $2 \cdot 12$ & $0 \cdot 88$ \\
\hline & & $0 \cdot 25$ & 0.28 & $0 \cdot 27$ & 0.06 & $0 \cdot 13$ & 0.07 & 0.01 & $0 \cdot 16$ & 0.07 & 0.01 & 0.09 & $0 \cdot 10$ \\
\hline p Value & & 0.0001 & 0.0001 & 0.0001 & 0.081 & 0.0001 & 0.03 & 0.83 & 0.0001 & 0.063 & 0.65 & $0 \cdot 006$ & 0.002 \\
\hline
\end{tabular}

${ }^{\star}$ Data incomplete in 13 cases.

Correlation of changes in serum cholesterol concentration with muscle tension and sleep disturbance scores tested by Spearman's rho and with remaining variables by Pearson's product moment correlation.

DISTRIBUTION OF CHANGES IN SERUM CHOLESTEROL CONCENTRATIONS IN RELATION TO CARDIOVASCULAR RISK FACTORS

Table IV shows a simple correlation analysis of changes in serum cholesterol concentrations between the two investigations in relation to changes in other coronary risk factors. Changes in body weight, haemoglobin and triglyceride concentrations, diastolic and systolic blood pressure, and plasma calcium concentration were significantly correlated with changes in the serum cholesterol concentration. Declines in pulmonary function (forced vital capacity) and glucose tolerance (fasting values and values 120 minutes after loading) were unrelated to changes in serum cholesterol concentrations.

Scores for muscle tension and sleep disturbance were significantly related to changes in serum cholesterol concentration. Of the 715 men in the study group, $261(36 \cdot 5 \%)$ had a lower serum cholesterol concentration at the second screening, and these men had significantly lower mean scores for muscle tension $(p=0.008)$ and sleep disturbance $(p=0.0018)$ than men with increased serum cholesterol concentrations. Figure 2 shows the scores for sleep disturbance in relation to changes in serum cholesterol concentrations in the whole series. Men who did not answer all the questions in the relevant section of the questionnaire (and were thus excluded) had the same mean value for change in serum cholesterol concentration as those who reported no sleep disturbance. The findings suggested a threshold effect (fig 2).

Table $\mathrm{V}$ gives the results of a multivariate analysis with change in serum cholesterol concentration as the dependent variable and including the other coronary risk factors as listed in table IV (psychological scores excluded). The correlation with four of these risk factors remained significant. A similar analysis was also made between changes in serum cholesterol concentra-

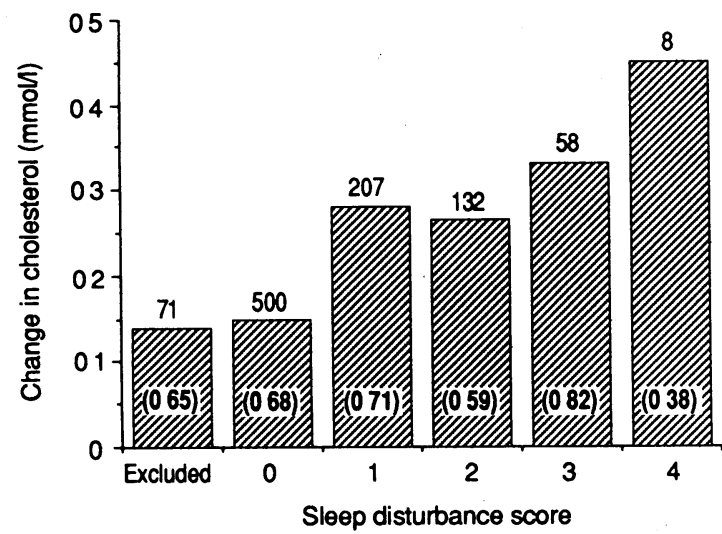

FIG 2-Mean change in serum cholesterol concentrations in relation to scores for sleep disturbance $(0=$ nil, $4=$ severe $)$. Figures above bars are numbers of subjects. Figures within bars are SDs. "Excluded" refers to men who did not answer all questions in relevant section of questionnaire tion and muscle tension and sleep disturbance. Sleep disturbance was the only significant variable included in the stepwise regression procedure (partial $\mathrm{R}^{2}=1 \cdot 4 \%$; probability $>\mathrm{F}=0 \cdot 0007)$.

TABLE V-Results of stepwise regression analysis with change in serum cholesterol concentration as dependent variable and including the variables listed in table IV (psychological scores excluded)

\begin{tabular}{lccc}
\hline Variable & $\begin{array}{c}\text { Partial } \mathbf{R}^{2} \\
(\%)\end{array}$ & Slope & p Value \\
\hline Change in haemoglobin concentration & $8 \cdot 1$ & 0.020 & 0.0001 \\
Change in weight & 6.3 & 0.035 & 0.0001 \\
Change in triglyceride concentration & 3.1 & $0 \cdot 144$ & 0.0001 \\
Change in calcium concentration & 1.0 & 0.717 & 0.001
\end{tabular}

\section{Discussion}

The unique feature of this study was the opportunity to undertake a prospective analysis of changes in cardiovascular risk factors in a large series of men exposed to the risk of a dramatic change in their livesthat is, of suddenly becoming unemployed. As the definite decision to close the plant was preceded by extensive discussion in the mass media regarding the future of the company it is reasonable to suppose that these men had been under psychological pressure for a considerable time. On the other hand, it was clearly stated that every effort would be made to find new jobs for all those who were to be laid off and that early retirement on full pay would be granted to the oldest group of employees (those aged 58.3 years and over). From the questionnaire survey it was plain that the older men in the study group had a lower frequency of such adverse psychological reactions as anxiety, depression, muscle tension, and sleep disturbance than the younger men. This difference may have been explained by the economic security guaranteed to older men in the study group as older controls had higher scores for these variables.

Analysis of subgroups elicited another striking difference in psychological reactions. Over $40 \%$ of the workforce at the shipbuilding yard had come to Sweden as adult immigrants as compared with $8 \%$ of controls assumed to be representative of male residents in Malmö. The immigrants had more symptoms of psychological tension and depression than did native Swedes. On the other hand, native Swedes working in the shipyard seemed to have somewhat fewer problems of this kind than Swedish men in general despite the current spate of lay offs. We have no explanation for this except that it may have been due to a "healthy worker" effect. Compared with the general population possibly Swedes working in the shipyard constituted a selection of mentally stable, healthy'men, many of whom had been working at the same place for a very long time, and who had faith in the Swedish welfare system and the promise by the company that individual solutions for future employment would be found.

The changes in 19 variables more or less clearly 
associated with cardiovascular disease were analysed during a period when a formerly stable source of employment changed into one fraught with the risk of job loss for most of the employees. Of the variables studied, only the changes in serum cholesterol and calcium concentrations differed between the study group and controls. The biological implication of the comparatively small change in serum calcium concentration is difficult to evaluate, especially as serum albumin values were not measured. From an earlier study we know that serum concentrations of both total calcium and ionised calcium decrease with age. ${ }^{17}$

Although theoretically a difference in lifestyle between the groups might have been a confounding factor, we found no evidence of any difference in diet, history of having received nutritional advice, recreational exercise, or alcohol consumption that might explain the difference in serum cholesterol concentrations. The section for preventive medicine runs an intervention programme for people with high blood lipid values, high blood pressure, and glucose intolerance; $64(9.0 \%)$ men in the study group and 30 $(11.5 \%)$ controls were enrolled in the programme.

With respect to the relation between stress and changes in plasma lipid concentrations there have been numerous reports of an increase in free fatty acid and blood cholesterol concentrations in association with stressful events (reviewed by Dinsdale and Herd ${ }^{18}$ ). In one study blood cholesterol values were found to be $10 \%$ higher in conjunction with job loss than when a new job was obtained. ${ }^{19}$ In rats stress not only increased the total serum cholesterol concentration but decreased the concentration of high density lipoprotein cholesterol significantly. ${ }^{20}$ These changes seemed to be mediated by endogenous opioids. In a Swedish study of unemployed women serum cholesterol concentrations were found to be increased for eight months after job loss and high density lipoprotein cholesterol values to be decreased. ${ }^{21}$ Thus change in the atherogenic index is greater than can be explained by an increase in total cholesterol alone. On the basis of multiple risk factor intervention trial data ${ }^{22}$ the values that we obtained for the increase in serum cholesterol concentrations in the shipyard workers were consistent with an increase in the relative risk of death due to coronary heart disease from 1.84 to 2.20 even without taking into account the possible aggravating effect of a decrease in high density lipoprotein cholesterol.

Although cholesterol seemed to be the most sensitive stress indicator in this study, there were positive correlations between change in cholesterol values and changes in blood pressure, triglyceride values, and haemoglobin concentration (table IV). Surprisingly, glucose tolerance did not seem to change with changes in cholesterol concentration, nor did urate values. Plainly, however, people with the greatest increase in cholesterol concentrations also have a deterioration in the overall risk factor profile that is not at all negligible.

In stepwise regression analysis change in haemoglobin concentration explained most of the change in the serum cholesterol concentration. Other studies have shown a correlation between serum cholesterol and serum haemoglobin concentrations in cases of sideropenic anaemia. ${ }^{23}$ Data on healthy people are sparse, but in one small series such a correlation was also found in young healthy adults of both sexes. ${ }^{24}$ To our knowledge no previous data have been published on the relation between changes in these two variables in healthy men.

There was a higher frequency of sleep disturbance in the study group than among the controls. Scores for sleep disturbance were significantly correlated with change in cholesterol values both in univariate analysis and in stepwise regression analysis. In several large scale longitudinal studies the risk of cardiovascular morbidity and mortality was found to be increased among subjects reporting sleep disturbance or daytime fatigue (reviewed by Siegrist ${ }^{25}$ ). Sleep disturbance seems to be a sensitive indicator of chronic or subacute socioeconomic distress such as stress at work and poor control over one's occupational setting..$^{25}$ To our knowledge there have been no other reports of a relation between sleep disturbance and an increased serum cholesterol concentration. A follow up study is needed to see whether this increase is important for future cardiovascular events.

In conclusion we found indications of a relation between the imminent risk of job loss and increases in the serum cholesterol concentration in a cohort of male shipyard workers. The increases were more pronounced in men with sleep disturbance and in immigrants and almost non-existent among men who were offered early retirement on full pay. Men with increased serum cholesterol concentrations also manifested increases in other established risk factors for cardiovascular disease, which might partly explain the high mortality in conjunction with unemployment and sleep disturbance reported in earlier epidemiological studies.

We thank the executive director and the staff of the personnel department at Kockums AB for their generous help in the execution of this study. The study was supported by grants from the Swedish Work Environment Fund.

\section{Appendix}

DETAILS OF QUESTIONNAIRE ASSESSING PSYCHOLOGICAL AND PSYCHOSOCIAL VARIABLES

Muscle tension-The section on muscle tension asked 11 questions: "Do you often strain your neck, your shoulders, your eyes, your brow, your stomach?" "Do you often hold your breath? grip tools harder than necessary? bite your teeth? grind your teeth? perch on a chair ready to leave? feel out of breath?"

Sleep disturbance - The section on sleep disturbance asked four questions: "Have you during the last six months had difficulty in waking up? nightmares? tiredness during working hours? tiredness of the eyes?"

Depression - The section on depression asked seven questions: "Do you feel that your life is meaningless?" "Have you wished to be dead?" "Have you been unable to sleep because of brooding?" "Do you feel as if you are carrying a heavy burden?" "Do you think that you are an unimportant person?" "Have you thought of suicide?" "Do you think that life is hopeless?"

Anxiety-The section on anxiety asked six questions: "Do you often feel bad tempered?" "Have you worried or felt panicky without reason?" "Do you always feel nervous or worried?" "Do you sometimes feel too nervous to be able to do anything?" "Do you feel that you are under pressure?" "Do you have difficulty going to sleep?"

Nutrition score-Dietary habits were evaluated by eight questions - for example, "Do you eat vegetables daily?" "Do you prefer white bread?" A high score indicated good dietary habits.

Alcohol consumption was evaluated by a modified version of the Michigan alcohol screening test (MAST) described by Kristensson and Trell. ${ }^{26}$ The test comprises nine questions about drinking habits - for example, "Do you feel that you should decrease your intake of alcohol?" "Do you usually drink a bottle of wine at weekends?" "Do you usually take a drink before you go to a party?" "Do you take a drink or two daily to relax?" A high score indicates a high alcohol intake.

1 Brenner $\mathrm{MH}$. Economic change, alcohol consumption and heart disease mortality in nine industrialized countries. Soc Sci Med 1987;25:119-32.

Starrin B Larson G, Brenner SO. Regional variations in cardiovascular mortality in Sweden-structural vulnerability in the local community. Soc Sci Med 1988;27:911-7.

3 Moser KA, Goldblatt PO, Fox AJ, Jones DR. Unemployment and mortality: comparisons of the 1971 and 1981 longitudinal study census sample. Br Med f 1987;294:86-90.

4 Beale N, Nethercott S. Job loss and health - the influence of age and previous morbidity. I R Coll Gen Pract 1986;36:261-4. 
5 Smith R. "He never got over losing his job": death on the dole. $\mathrm{Br}$ Med $\mathrm{f}$ 1985;291:1492-5.

6 Smith R. "I'm just not right": the physical health of the unemployed. Br Med $\mathcal{F}$ 1985;291:1626-9.

7 Sabroe S, Iversen L. Unemployment, social support, psychological well-being and psychosomatic symptoms. In: Starrin B, Svensson PG, Winterberger $\mathrm{H}$, eds. Unemployment, poverty and quality of working life-some European experiences. Berlin: Edition Sigma (in press).

8 Kripke DF, Simons RN, Garfinkel L, Hammond EC. Short and long sleep and sleeping pills. Is increased morbidity associated? Arch Gen Psychiatry 1979;36:103-16.

9 Wingard DL, Berkman LF. Mortality risk associated with sleeping pattern among adults. Sleep 1983;6:102-7.

10 Berntorp K, Trell E, Thorell J, Hood B. Relation between plasma insulin and blood glucose in a cross-sectional population study of the oral glucose blood glucose in a cross-sectional population study of

11 Lindberg W, Natvig H, Rygh A, Svendsen H, Høyde- och viktundersøkelser hos voksne menn och kvinner. Tidsskr Nor Laegeforen 1956;11:361-8.

12 Goldberg D. Manual of the personal health questionnaire. Windsor: National Foundation for Educational Research, 1978.

13 Åkerstedt T, Gillberg M. Experimentally displaced sleep. Effect on sleepiness. Electroencephalogr Clin Neurophysiol 1982;54:220-6.

14 Åkerstedt T, Torsvall L, Gillberg M. Sleepiness and shift work: field studies. Sleep 1982;5:95-106.

15 Theorell T, Ahlberg-Hulthén G, Berggren T, et al. Arbetsmiljö, levnadsvanor och risk för hïärt-kärlsjukdom. Stockholm: National Institute for Psychosocial Factors and Health, Karolinska Institute, 1987. (Stress research report No 195.)

16 Theorell T, Harms-Ringdahl K, Ahlberg-Hulthén G, Westin B. Psychosocial job factors and symptoms from the spine and joints-a multicausal analysis. Scand f Rehabil Med (in press).
17 Lindgärde F. Potentiometric determination of serum ionized calcium in a normal human population. Clin Chim Acta 1972;40:477-84.

18 Dimsdale JE, Herd JA. Variability of plasma lipids in response to emotional arousal. Psychosom Med 1982;44:413-27.

19 Kasl S, Cobb S, Brooks G. Changes in serum uric acid and cholesterol levels in men undergoing job loss. FAMA 1968;206:1500-7.

20 Bryant HU, Story JA, "Yim GKW. Assessment of endogenous opioid mediation in stress-induced hypercholesterolemia in the rat. Psychosom Med 1988;50:576-85.

21 Arnetz BB, Brenner SO, Hjelm R, Levi L, Pettersson I. Stress reactions in relation to threat of job loss and actual unemployment. Stockholm: National Institute for Psychosocial Factors and Health, Karolinska Institute, 1988. (Stress research report No 206.)

22 Stamler J, Wentworth D, Neaton JD. Is relationship between serum cholesterol and risk of premature death from coronary heart disease continuous and grade

23 Ohira Y, Edgerton R, Gardner GW, Senewiratne B. Serum lipid levels in iron deficiency anemia and effects of various treatment. $\mathcal{F}$ Nutr Sci Vitaminol Tokyo) 1980;26:375-9.

24 Medeiros D, Pellum L, Brown B. Serum lipids and glucose as associated with haemoglobin levels and copper and zinc intake in young adults. Life Sci 1983;32:1897-1904.

25 Siegrist J. Sleep disturbances and cardiovascular risk: a biopsychosocial approach. In: Peter IH, Podstus T, Wichert PV, eds. Sleep related disorders and internal disease. Berlin: Springer, 1987:173-82.

26 Kristensson $\mathrm{H}$, Trell $\mathrm{E}$. Indicators of alcohol consumption. Comparisons between a questionnaire (Mn-MAST), interviews and serum-gammaglutamyltransferase (GGT) in a health survey of middle aged males. Brf Addict 1982;77:297-304.

(Accepted 19 fune 1990)
St Mary's Hospital,

Mumias, Kakamega

District, Kenya

M Keuter, MD, consultant

physician

Wilfreda A Ngwawe, nursing

officer in charge

Free University

of Amsterdam,

The Netherlands

Annemiek van Gijk, medical

student

Marjan Hoogstrate, medical

student

University of Amsterdam,

Amsterdam, The

Netherlands

Maarten Raasveld, medical

student

Marcel van der Ree, medical student

Wellcome Trust Research

Laboratories, Nairobi,

Kenya

William M Watkins, PHD,

interim director

Clinical Research Centre,

Kenya Medical Research

Institute, Nairobi, Kenya

Joab B O Were, MD, director

Division of Parasitic

Diseases, Center for

Infectious Diseases,

Centers for Disease

Control, Atlanta, Georgia,

United States

A David Brandling-Bennett,

MD, visiting scientist, Clinical

Research Centre

Correspondence to:

Dr Monique Keuter,

Department of Intensive

Care, Sint Radboud

Ziekenhuis, PO Box 9101,

6500 HB Nijmegen,

The Netherlands.

BrMed F 1990;301:466-70

\section{Comparison of chloroquine, pyrimethamine and sulfadoxine, and chlorproguanil and dapsone as treatment for falciparum malaria in pregnant and non-pregnant women, Kakamega district, Kenya}

Monique Keuter, Annemiek van Eijk, Marjan Hoogstrate, Maarten Raasveld, Marcel van de Ree, Wilfreda A Ngwawe, William M Watkins, Joab B O Were, A David Brandling-Bennett

\section{Abstract}

Objective-To compare treatment and protection against falciparum malaria in pregnant and nonpregnant women with three drug regimens.

Design-Prospective intervention study with six weeks' follow up. Patients received one of three drug regimens in order of entry.

Setting-Primary care hospital and secondary girls' school in rural western Kenya.

Patients -158 Of 988 pregnant women (89 primigravid and 69 multigravid) in the third trimester and 105 of 1488 non-pregnant schoolgirls of reproductive age were parasitaemic (more than 500 asexual forms $/ \mu$ l. These women were divided into three treatment groups by gravid state.

Interventions - Women were treated with chloroquine base $25 \mathrm{mg} / \mathrm{kg}$ over three days or pyrimethamine $75 \mathrm{mg}$ and sulfadoxine $1500 \mathrm{mg}$ as a single dose or chlorproguanil $1.2 \mathrm{mg} / \mathrm{kg}$ and dapsone $2.4 \mathrm{mg} / \mathrm{kg}$ as a single dose.

Main outcome measures-Parasitaemia and haemoglobin concentrations measured at seven day intervals for six weeks.

Results-Primigravid women were more likely to be parasitaemic on follow up than multigravidas or nulligravidas, whose response was about the same. Parasites did not clear by day 7 in primigravidas in six $(20 \%)$ of 30 who received chloroquine, three $(8 \%)$ of 35 treated with pyrimethamine and sulfadoxine, and none of $\mathbf{2 3}$ treated with chlorproguanil and dapsone. At day $28,83 \%, 19 \%$, and $67 \%$ of primigravidas in these treatment groups were parasitaemic. Haemoglobin concentrations rose in all women, but improvement was sustained only in women who remained free of parasites.

Conclusions-Clearance of parasites was better with either pyrimethamine and sulfadoxine or chlorproguanil and dapsone than with chloroquine.
Longest protection was obtained with pyrimethamine and sulfadoxine.

\section{Introduction}

Pregnant women, especially primigravidas, are more vulnerable than non-pregnant women to malaria infections. Infection may result in stillbirth, low birthweight infants, and anaemia in the mother. ${ }^{1-4}$ The World Health Organisation recommends that pregnant women receive chemoprophylaxis with chloroquine base, $5 \mathrm{mg} / \mathrm{kg}$ body weight weekly, in areas where Plasmodium falciparum is sensitive to the drug.'

In 1986 it was reported that chloroquine $5 \mathrm{mg} / \mathrm{kg}$ weekly and chloroquine $25 \mathrm{mg} / \mathrm{kg}$ monthly did not completely protect pregnant women in western Kenya. ${ }^{6}$ We found in 1987 that $90 \%$ of infections with $P$ falciparum in children under 5 years in western Kenya were resistant to chloroquine (unpublished data).

Two alternatives to chloroquine, amodiaquine and pyrimethamine with sulfadoxine, are no longer recommended for routine prophylaxis because of serious, though uncommon, side effects. ${ }^{7.9}$ The dihydrofolate reductase inhibitors pyrimethamine and chlorproguanil are not effective as prophylactic drugs in Kenya when given alone. ${ }^{10-12}$ Therefore only a limited number of drugs is available for effective prophylaxis.

A recent report indicates that the combination of chlorproguanil and dapsone is more effective than pyrimethamine and sulfadoxine in vitro and as effective in vivo against $P$ falciparum in Kenya. ${ }^{13}$ Because the chlorproguanil and dapsone combination is eliminated more rapidly than pyrimethamine and sulfadoxine, in one week compared with about eight weeks, chlorproguanil and dapsone may exert less pressure than pyrimethamine and sulfadoxine for the 